九病虫研会報 $31: 77-81(1985)$

Proc. Assoc. Pl. Prot. Kyushu $31: 77-81$ (1985)

\title{
キウイフルーツ果実軟腐症の発生と薬剂防除
}

磯田 隆晴 ·上村 道雄（熊本県果樹試験場）

\section{Occurrence and chemical control of fruit rot of kiwifruit.}

Takaharu ISODA

and Michio UemuRa (Kumamoto Fruit-Tree Experiment Station, Shimomashiki-gun Kumamoto 869-05)

熊本県でのキウイフルーツ栽培は，ここ10年程前から 始まり, 栽培面積も年々増加している。当初は, 病害虫 の発生も少なく，比較的作り易い樹種といわれていたが, 最近になって，栽培面積が増加し，樹令が進むなかで 種々の病害虫被害が発生するようになった。収穫後貯蔵 して追熟させてから出荷するキウイフルーツにとっては, 貯蔵果実の腐敗は大きな問題となっている。特に，果実 軟腐症は，出荷直前に発生するため，経済的な損失と同 時に栽培者にとっては，経営に対する意欲阻害となり， 市場から不評をかう原因となっている。果実軟腐症の発

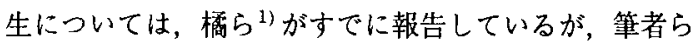
は貯蔵中に発生する腐敗果実について, 発生の種類と若 干の防腐対策試験を行ってきたので，概要を報告する。 なお，本試験を行うに当たり，宇城普及所寺田喜義，宇 城園芸連平田繁富雨技術員に協力戴いた。ここに深謝の 意を表する。

\section{1. 県内での腐敗果発生調查}

熊本県で生産されるキウイフルーツの大部分は, 宇城 園芸連の貯蔵庫に収穫後冷温貯蔵されるが，入庫時に， 各生産者から30個抜き取り，12月下旬から 1 月下旬まで 常温貯蔵により腐敗果実の発生を調查した。結果は第 1

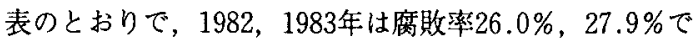
あったが，1984年は $43.2 \%$ 発生した。腐敗果の発生は, 町村別ではほとんど変わらないが，生産者による個人差 が大きく，1984年の調査では，農家数48戸のうち15戸で $80 \%$ 以上の腐敗が見られた。

\section{第 1 表 県内での年次別腐敗果発生調査}

\begin{tabular}{lrrr}
\hline & \multicolumn{3}{c}{ 調 查 年 次 } \\
\cline { 2 - 4 } 項 目 & 1982 & 1983 & 1984 \\
\hline 調查町村 & 8 & 9 & 12 \\
生産者数 & 35 & 40 & 48 \\
調查果数 & 1,050 & 1,200 & 1,440 \\
噟敗果数 & 273 & 335 & 622 \\
䧹敗果率 $(\%)$ & 26.0 & 27.9 & 43.2 \\
\hline
\end{tabular}

\section{2. 腐敗果実の種類と病原菌の分離}

眝蔵中ならびに收穫前の果実腐敗について発生症状の 類別, PDA 培地による菌の分離, 再接種を行った。結 果は次のとおりである。

1）果実円形状腐敗：通常果実軟腐症といわれている 腐敗で、貯蔵果実では最も発生が多い。腐敗果実の $90 \%$ 以上は本病による腐敗である。発生時期は，貯蔵後期の 追熟が進んで，果実が食に供される程度に軟化したころ から急激に発生してくる。発生初期は, 見ただけでは判 り難く, 手に触って部分的に軟腐しているのを感触で判 別される。軟腐が進むと，果実表皮が赤褐色になり，ま た，指で押したようなくぼみを生ずることもある（第 1 図)。このような果実の表皮を削ぐと果肉部に円形状の 病斑が見られる(第 2 図)。病斑の中心部に白色斑があ り，その周囲は濃緑色の軟化組織が円形状に拡がってい る。病斑は 1 数個が果面全体に散在し, 病勢進展によ り大小様々の大きさがみられる。病原菌の分離結果は第 2 表のと扔りで, Botryoshaeria sp. が高頻度に分離され， 再接種による発病も確認された。

2）白斑症：冷温貯蔵をしているときに発生を確認し た。果実はまだ硬く, 後熟中の果実で発生を認め, 園に より発生が集中しているように思われる。表皮に 2 ミリ 程度の赤褐色斑が散在し，このような果実をナイフで削 ると，内部に白色斑が見られる(第 3 図)。これを常温 下に移すと数時間で白色斑の周囲が浸潤して淡黄色に腐 敗してくる。硬い果実に発生することから，軟化した部 分を除去するとクレータ状を呈する（第 4 図）。白色斑 や軟化した部分を分離すると, 第 3 表のように大部分 Phomopsis sp. が検出される。しかし, 接種による白色斑 の再現は実施していない。

3）果梗部からの腐敗：果梗部から腐敗してくるのが 特徴で, 果梗周辺の果実表面には灰白色 灰黑色の菌系 が発生することがある（第 5 図）。果梗は褐変しており， 腐敗部の表皮を削ぐと果肉は崩壊され軟腐して激しい異 
第 2 表 果実円形状腐敗からの分離

\begin{tabular}{|c|c|c|c|}
\hline \multirow{2}{*}{ 分離部位 } & \multirow{2}{*}{$\begin{array}{l}\text { 分 } \\
\text { 離 } \\
\text { 数 }\end{array}$} & \multicolumn{2}{|c|}{ 分 離 率 (\%) } \\
\hline & & Botryosphaeria sp. & Phomopsis sp. \\
\hline \multirow{3}{*}{$\begin{array}{c}\text { 果側部の軟腐 } \\
\text { (円形腐敗) }\end{array}$} & 果肉 ${ }^{1)} 139$ & 98.6 & 0.7 \\
\hline & 果肉 $^{2)} 100$ & 99.0 & 0 \\
\hline & 表皮 ${ }^{1)} 216$ & 8.3 & 63.9 \\
\hline 果梗部の軟腐 & 果肉 ${ }^{1)} 468$ & 58.3 & 28.8 \\
\hline (円形腐敗が & 果肉 $^{2)} 61$ & 77.0 & 11.3 \\
\hline 混在して発 & 表皮 ${ }^{1)} 104$ & 9.6 & 58.7 \\
\hline 生している) & 表皮 ${ }^{2)} 156$ & 18.6 & 70.5 \\
\hline
\end{tabular}

注）1）1983年12月分離

2) 1984 年12月分離

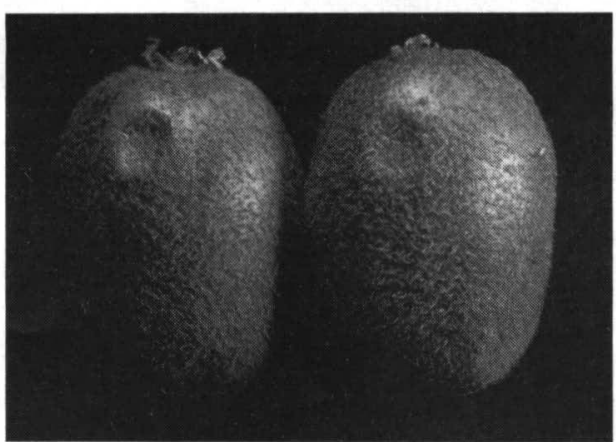

第 1 図果実円形状腐敗（軟腐症）の外観症状

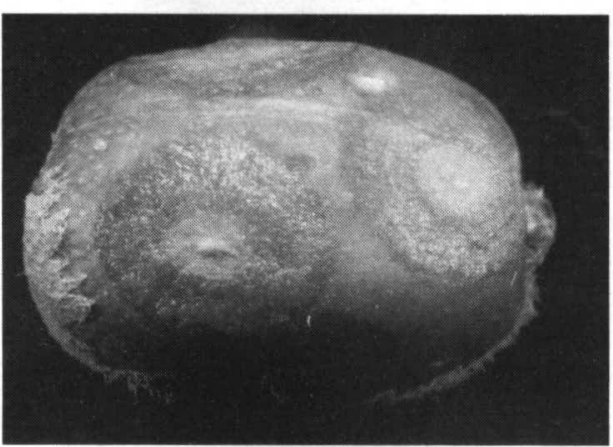

第 2 図果実円形状腐敗（軟腐症）

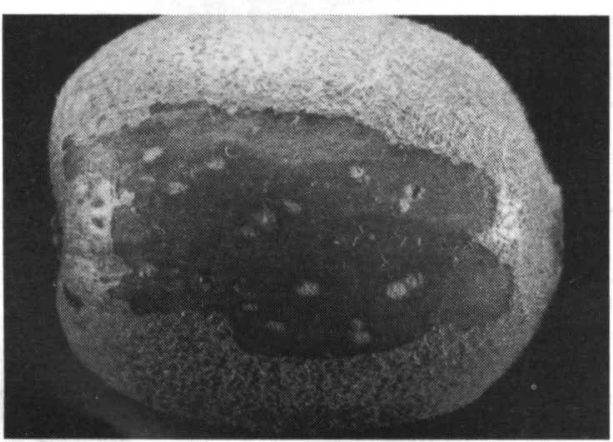

第3図白斑症
第 3 表 白斑症およびその周囲軟化部からの分離

\begin{tabular}{llcc}
\hline \hline \multirow{2}{*}{ 分離部位 } & 分 & \multicolumn{2}{c}{ 分 離 } \\
\cline { 3 - 4 } & 率 $(\%)$ \\
\cline { 3 - 4 } & 数 & Botryosphaeria $\mathrm{sp}$. & Phomopsis sp. \\
\hline 果実内部の白斑部 & 35 & 2.9 & 97.1 \\
"の白斑周边の軟化部 & 20 & 5.0 & 95.0 \\
\hline
\end{tabular}

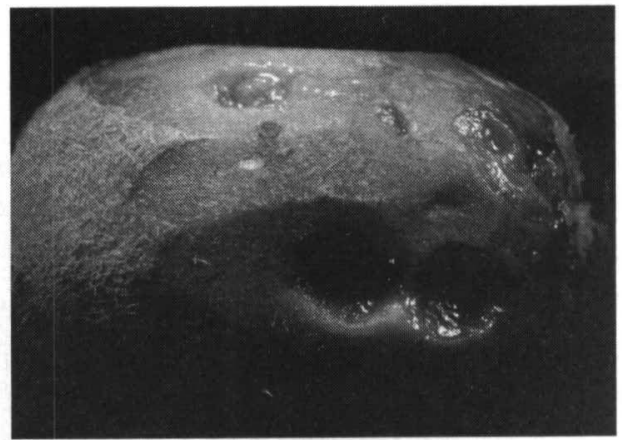

第4図白斑症腐敗

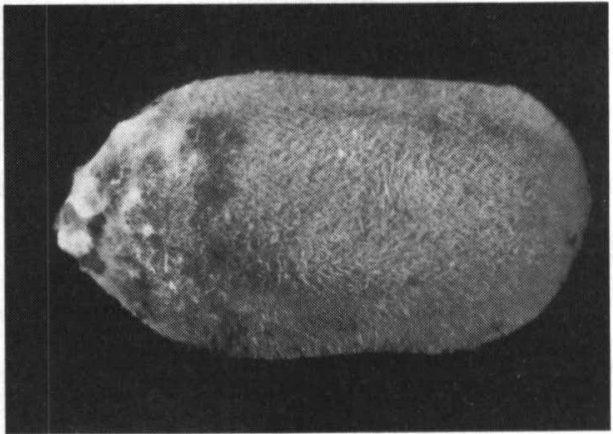

第 5 図果梗部からの腐敗

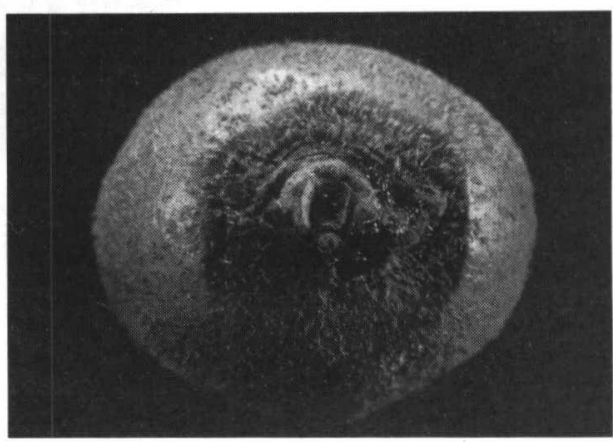

第 6 図果梗部の腐敗 
第 4 表 果梗部腐敗からの分離

\begin{tabular}{|c|c|c|c|c|}
\hline \multirow{2}{*}{ 分離部位 } & & \multirow{2}{*}{ 分離数 } & \multicolumn{2}{|c|}{ 分離率 $(\%)$} \\
\hline & & & $\begin{array}{l}\text { Botryo- } \\
\text { sphaeria sp. }\end{array}$ & $\begin{array}{l}\text { Phomo- } \\
\text { psis sp }\end{array}$ \\
\hline 果梗部の腐敗 & 果肉 & 72 & 0 & 88.9 \\
\hline $\begin{array}{l}\text { (円形腐敗の) } \\
\text { 発生はない) }\end{array}$ & 果芯 & 44 & 9.1 & 90.9 \\
\hline 軟腐症は発生してい & 表皮 & 18 & 0 & 100.0 \\
\hline $\begin{array}{l}\text { ないが, 果梗周辺の } \\
\text { 表面に菌系発生 }\end{array}$ & 果肉 & 16 & 0 & 6.3 \\
\hline 果頂部の軟腐 & 果肉 & 16 & 25.0 & 75.0 \\
\hline
\end{tabular}

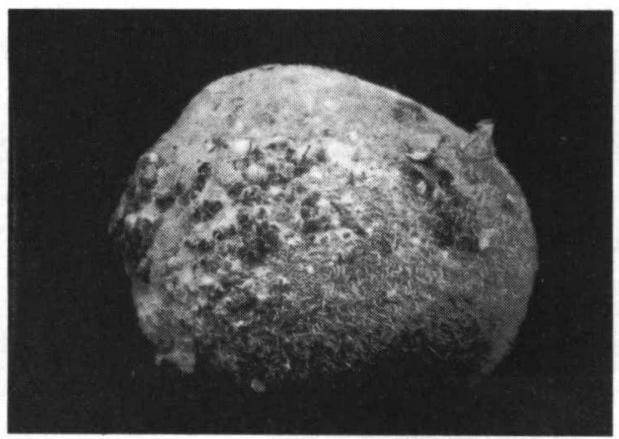

第 7 図灰色かび病菌による腐敗

臭がある。一般に追熟が進んだ果実で発生が多いが，冷 温貯蔵果実で，まだ硬い状態のものでも，へ夕枯れをお こし果梗部周辺だけ腐敗していることがある (第6図)。 病原菌の分離では第 4 表にしめすように, Phomopsis sp. が検出され，再接種による腐敗も確認された。

4) 灰色かび病菌による腐敗：冷温貯蔵果実で腐敗果 の発生が認められた。果実全体が灰白色の菌そうに覆わ れ，接触した果実はいずれもその部分から軟化してくる。 腐敗が進むと果実表面には黒色の菌核を形成し（第 7 図)，著しい異臭がある。病原菌の分離では第 5 表のよ うに，いずれもBotrytis sp. 菌が検出され，再接種によ る腐敗も確認された。

5）収穫前の落果における腐敗：9，10月に立木中に 果実が落果することがある。園や年次間差があるが, 落 果した果実はいずれも果梗部から腐敗する。果肉は軟腐 し，異臭がある。菌を分離するといずれもPhomopsis sp. 菌が検出された。

\section{3. 薬剤防除試験}

貯蔵中の果実腐敗に対する薬剤防除試験を行った。腐 敗果実はいずれもBotryosphaeria sp. 菌による果実軟腐症 である。
第 5 表 灰色かび病菌による腐敗果からの分離

\begin{tabular}{|c|c|c|c|}
\hline \multirow{2}{*}{ 分離部位 } & \multirow{2}{*}{ 分離数 } & \multicolumn{2}{|c|}{ 分離率 (\%) } \\
\hline & & Botrytis sp. & Phomopsis sp. \\
\hline $\begin{array}{l}\text { 灰白色腐敗 } \\
\text { 果実の果肉部 }\end{array}$ & 10 & 100.0 & 0 \\
\hline $\begin{array}{l}\text { 接触した果 } \\
\text { 実の軟化部 }\end{array}$ & 10 & 90.0 & 10.0 \\
\hline
\end{tabular}

第 6 表 収穫前の落果からの分離

\begin{tabular}{|c|c|c|c|}
\hline 分離部位 & \multirow{2}{*}{$\frac{\text { 分離数 }}{20}$} & \multicolumn{2}{|c|}{$\begin{array}{l}\text { Phomopsis sp. } \\
\text { の分離率 (\%) }\end{array}$} \\
\hline 果梗部 果肉 & & & 95.0 \\
\hline 第 7 表 & \multicolumn{3}{|c|}{ 収穫前の散布による防除効果 } \\
\hline 供試薬剤 & 濃度 (倍) & 調査果数 & 腐敗果率 (\%) \\
\hline マデイック乳剂 & 2,000 & 313 & 66.1 \\
\hline グアザチン液剂 & 1,000 & 243 & 53.5 \\
\hline $\begin{array}{l}\text { チオファ衤ート } \\
\text { ×チル水和剤 }\end{array}$ & 1,000 & 427 & 51.3 \\
\hline 無 散 布 & & 561 & 48.6 \\
\hline
\end{tabular}

第 8 表 収穫後の果実浸漬による防除効果

\begin{tabular}{|c|c|c|c|c|c|c|}
\hline \multirow{2}{*}{ 供試薬剤 } & \multirow{2}{*}{$\begin{array}{c}\text { 濃 } \text { (度) } \\
\text { (倍) }\end{array}$} & \multirow{2}{*}{$\begin{array}{l}\text { 調 査 } \\
\text { 果 数 }\end{array}$} & \multicolumn{3}{|c|}{ 果梗痕の変色 (\%) } & \multirow{2}{*}{ 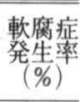 } \\
\hline & & & 緑色 & 黄色 & 褐色 & \\
\hline グアザチン液剂 & & & 26.7 & 30.0 & 43.3 & \\
\hline ベノミル & & & .0 & 40.0 & 40.0 & \\
\hline マリックス乳剂 & 3,000 & 30 & 70.0 & 10.0 & 20.0 & 80.1 \\
\hline 無 処 理 & & 30 & 3.3 & 36.7 & 60.0 & 75.0 \\
\hline
\end{tabular}

1) 収穫前の薬剤散布 : 収穫 1 週間前に動噴で薬剤を 散布して，10月26日に果実を収穫した。その後常温貯蔵 したが，第 7 表にしめすように腐敗防止効果は全く認め られなかった。

2) 果実の浸漬効果：収穫した果実を各種薬剤に浸漬 して, 果梗部の変色 (褐変) ならびに腐敗果の発生を調 査した。結果は第 8 表のとおりで, マリックス乳剂 3,000倍は, 果梗部の変色防止効果が高かったが, 腐敗 果の発生防止効果を示さなかった。他の 2 薬剤は変色防 止効果, 腐敗果の発生防止効果のいずれも示さなかった。

3）生育期散布：1982年は6月と 7 月に 2 回手押散布器 で果実重点に散布し，10月25日に収穫して常温貯蔵した。 結果は第 9 表のとおりで, チオファネートメチル水和剤 でやや腐敗が少ない傾向にあるが, 総体的には不十分な 効果であった。1984年は 5 月から 9 月まで10回動噴で散 布し，10月26日に収穫して常温貯蔵を行った。結果は第 10表のとおりで, 完全に防除出来たものはなかったが, 
チオファネートメチル水和剤, ホセチルマンゼブ混合剤 でやや高い効果がみられた。なお，水酸化第二銅水和剂 は果実に赤褐色污染の薬害を生じた。

\section{考察}

キウイフルーッの果実腐敗は, 発生症状から 5 種類を 確認したが，病原菌により，腐敗は 3 種類に類別される。

一つは, Botryosphaeria sp. 菌による腐敗で，3ヶ年の 調查では最も発生頻度が高かった。熊本県での果実腐敗 は大部分が本菌によるものである。ニュージーランドで も発生が多く, PENNEYCOOK' ${ }^{2}$ は病原菌を Botryosphaeria dothidea としてRIPE Rot を報告しているが, 発生症状 から同じ病気と思われる。B. dothidea は，枯枝又は枯れ かかった樹皮の中に分生胞子と子のう胞子を形成して， 雨滴に混って伝搬する。防風林のヤナギやポプラが伝染 源である可能性が高いとしているが，本県では，園に近 い雑木林からの感染が考えられ，整枝，剪定など園の管 理が，不十分なところで多く発生している。

Phomopsis sp. 菌による腐敗は果梗部から腐るのが典型 的な症状であるが，収種前に落果する腐敗果実も同じ病 気と思われる。これらの病気は腐敗が進むと果実の表面 に白色一灰白色の菌系が付着するが，果肉は軟腐して異

第 9 表 生有期の散布效果 (6，7月の 2 回散布)

\begin{tabular}{|c|c|c|c|c|c|}
\hline \multirow{2}{*}{ 供試薬郕 } & \multirow{2}{*}{$\begin{array}{c}\text { 濃度 } \\
\text { (倍) }\end{array}$} & \multirow{2}{*}{$\begin{array}{l}\text { 供試 } \\
\text { 果数 }\end{array}$} & \multirow{2}{*}{$\begin{array}{l}\text { 落 } \\
\text { 褁 } \\
\text { 数 }\end{array}$} & \multicolumn{2}{|c|}{ 軟腐症発生率（\%) } \\
\hline & & & & 11月 8 日 & 11月 24 日 \\
\hline マンゼブ水和鼡 & 600 & 40 & 5 & 34.3 & 88.6 \\
\hline $\begin{array}{l}\text { チオファネート } \\
\text { メチル水和剂 }\end{array}$ & 1,000 & 40 & 3 & 21.6 & 78.4 \\
\hline ダイホルタン水和剤 & 1,000 & 40 & 1 & 61.5 & 79.5 \\
\hline ジネ ブ 水 和 浏 & 500 & 40 & 4 & 75.0 & 100.0 \\
\hline 無 散 布 & & 40 & 5 & 45.7 & 80.0 \\
\hline
\end{tabular}

臭を放つのが特徵である。発病果は必ず果梗部が腐敗し ており，発生機構はカンキッの軸腐れ病と類似するもの と思われる。なお，冷温貯蔵果実の白斑症からはいずれ もPhomopsis sp. 菌が分離されたが，発生の症状として はむしろ Botryosphaeria sp. 菌による腐敗の初期症状に類 似する。接種による白斑症の再現試験を実施していない ので，これを含めた発生原因の解析が今後必要である。

Botrytis sp. 菌による腐敗は冷温貯蔵果実で認められた。 発生は稀に見られる程度であるが，接触した果実が次々 に腐敗することから注意を要する。

眝蔵中の果実腐敗に対する薬剤防除試験を行った結果, 収穫前の薬剂散布, 収穫した果実での浸漬処理ではいず れも効果は認められなかった。これは病原菌が収檴時あ るいは貯藏中に感染して発病するのではなく，すでに生 育期に果実感染して潜伏していることを示すものと思わ れる。

PENNYCOOK²) は生育期に,ビンクロゾリン剂，イプロ ジオン郕を散布した園では腐敗果の発生が少なく，べ， ミル剂，キャピタフォル甋も有効であることを報告して いる。筆者らは, 生育期に数種類の殺菌剂を散布して防 除効果を検討したが，その結果チオファネートメチル棛， ホ七チル混合剂が有効であることがわかった。しかし， 5 月下旬から 9 月まで10回散布したにもかかわらず，満 足のいく効果ではなかった。本病は, 外観から腐敗して いるかどうかを見極めるのは困難である。市場に安心し て出荷するためには完全防除が望まれ，そのためには薬 㓲防除だけで発生を抑える事は難しく，今後袋かけ等を 含めた総合防除対策を検討していく必要があると考える。

摘

要

キウイフルーツは収椎後一定期間追熟するが，その間 に発生する腐敗果実について，種類と症状の検討ならび

第 10 表 生育期の散布効果（5月から9月まで10回散布）

\begin{tabular}{|c|c|c|c|c|c|c|c|}
\hline \multirow{2}{*}{ 供試薬剂 } & \multirow{2}{*}{${ }_{(\text {傮 }}{ }^{\text {度 }}$} & \multirow{2}{*}{ 供試果数 } & \multicolumn{5}{|c|}{ 果実軟腐症の発生率（\%) } \\
\hline & & & 11月29日 & 12月 7 日 & 12月18日 & 12月24日 & 1 月 11 日 \\
\hline ビンクロゾリン水和剂 & 1,000 & 295 & 0.3 & 0.7 & 34.6 & 68.8 & 84.1 \\
\hline ビンクロゾリン水和剤 & 1,500 & 281 & 0 & 0.4 & 35.9 & 66.5 & 76.2 \\
\hline チオファネートメチル水和剤 & 1,000 & 277 & 0 & 0 & 18.1 & 66.1 & 79.4 \\
\hline ビンクロゾリンマンゼブ混合剂 & 600 & 126 & 0.8 & 4.8 & 64.3 & 82.5 & 96.8 \\
\hline ホセチルマンゼブ混合剤 & 600 & 76 & 0 & 1.3 & 9.2 & 34.2 & 57.9 \\
\hline キャプタンホセチル混合剤 & 1,000 & 304 & 0 & 0.3 & 32.9 & 50.7 & 54.9 \\
\hline $\begin{array}{l}\text { 水酸化第二銅水和剂 } \\
\text { (炭酸カルシウム郕混用 200) }\end{array}$ & 2,000 & 364 & 1.9 & 4.1 & 60.7 & 79.9 & 93.1 \\
\hline 有機銅 $80 \%$ 水和剤 & 500 & 252 & 1.2 & 3.6 & 92.8 & 98.0 & 99.6 \\
\hline 散 & & 828 & 1.6 & 3.5 & 56.6 & 81.0 & 90.1 \\
\hline
\end{tabular}


に病原菌の分離を行った。その結果, 立木中の早期落果 する腐敗を含め 5 種類の発生症状を䜅め, 病原菌の分離 から, Botryosphaeria sp., Phomopsis sp., Botritis sp.の 3 種類の菌による腐敗を確認した。その中で, 最も発生が 多いのはBotryosphaeria sp. 菌による腐敗で, 全体の 9 割 以上をしめていた。

本病対策のため薬剤試験を行ったが，チオファネート メチル剤，ホセチル混合剤で効果が認められたものの, 10 回散布でも $50 \%$ 以上が腐敗した。果実軟腐症は出荷時
に腐敗しているかどうか，外観からわかりにくいことか ら，完全防除が望まれ，今後はさらに的確な総合防除对 策について検討する必要がある。

\section{引用文献}

1）楧 泰宣·佐川正典·大森尚典（1983） 日植病報49：403 (講要). 2) RENNYCOOK, S. R. (1981) Orchardist of Newzealand $54: 392-394$.

(1985年 5 月 16 日 受領) 